\title{
Comparison Elicitation Techniques in Furniture Manufacture Requirement
}

\author{
Johanes Fernandes Andry ${ }^{1,3^{*}}$, Hadiyanto ${ }^{2}$, and Vincensius Gunawan Slamet Kadarisman ${ }^{2}$ \\ ${ }^{1}$ Doctoral Program of Information System, School of Post Graduate Studies, Diponegoro University, \\ Semarang, Indonesia \\ ${ }^{2}$ Department of Doctor of Information System, Diponegoro University, Semarang, Indonesia. \\ ${ }^{3}$ Department of Information System, Universitas Bunda Mulia, Jakarta, Indonesia
}

\begin{abstract}
The development of the industrial revolution 4.0 in manufacturing has changed conventional business processes to become automated, especially in the furniture sector. The constraints faced by the furniture manufacturing industry are that producers do not have a reporting tool that estimates how many products to sell, goods produced do not match their needs and stock errors. Therefore, the process of extracting needs is an important phase in the development of information systems because it determines the final outcome of the program. The research aims to define system requirements, so that it can help the decision-making process based on real-time data. This study describes the use of system planning techniques in the form of collaborative techniques, observational techniques and contextual techniques, which are combined with the Wellsandt evaluation criteria and measured using the low, medium and high scales. The results of this study are the acquisition of any business process areas that have a high level of difficulty to be prioritized and described in the form of a spider diagram. Implication of this research is that requirements can be used by developers to prioritize areas of business processes that must be improved in making decision support systems.
\end{abstract}

\section{Introduction}

The industrial revolution 4.0 in manufacturing is developing rapidly, changing conventional business processes to become automated [1-2]. This development is needed to facilitate human work, especially communication and monitoring [3]. The development of manufacturing companies that are getting faster makes companies have to adjust themselves [4]. Initial business processes that run in a company or organization can be modelled in requirement elicitation. The knowledge generated can be documented in the context of building and developing information systems [5]. In general, the business processes running in the company have been set manually based on the rules and procedures that have been implemented in the organization. Exploring needs is an essential

* Corresponding author: jandry@bundamulia.ac.id 
phase in the program development process because it is the most crucial stage in determining its outcome [6].

Requirement elicitation is the process of collecting, exploring, finding and studying the needs of customers, users and stakeholders, so that the application developed can help solve problems and meet customer needs [7-8]. The requirement elicitation process is expected to determine user expectations and obtain the essential requirements for the program's success [9-10]. The application of requirement elicitation in the manufacturing industry can help understand the problems that arise by translating inappropriate or incomplete needs and desires from users to obtain complete and precise specifications [11-12]. The constraints faced by the manufacturing industry in general and the furniture sector, in particular, are that producers do not have a reporting tool that allows them to estimate how much they will have to sell in the next few months, and the goods produced do not match what customers need.

Based on this, the authors compile requirement elicitation, which aims to assist the decision-making process based on real-time data, and there is no shortage of data due to the overly varied products. During the chair production process, it is necessary to know what the raw material components are used, so users need to know what items are being released from the warehouse and deal with the problem of excess material. It will show the efficiency of the material used throughout the production process [13-14].

This research starts from the process of formulating the objectives of making requirements and making research questions. The author identifies the needs of the problems experienced and analyzes the interested stakeholders. Then, the techniques, approaches, and tools used were selected, namely collaborative, contextual, and observational. In addition, the authors also combine these three techniques with requirement elicitation techniques that are by the production business process. The output generated from this study will be described in the form of a spider diagram.

\section{Charateristics of Requirements Elicitation}

The characteristics of requirements elicitation are described in several ways, namely collaborative (stakeholder expertise), observational (system understanding and knowledge) and contextual (user requirements) [15-16], contextual (user requirements) [17-18]. The elicitation techniques are classified into brainstorming, workshops, Joint Application Development (JAD), group work, ethnography, introspection and user scenarios [19-20]. According to Wellsandt, the evaluation criteria are divided into two groups. First, the terms of information collection consist of Proximity to Use (PTU), Effort Per User (EPU) and Required Skills (SKI). Second, the quality of feedback information consists of Structure (STR), Richness (RIC) and Quantifiability (QUA) [21-22].

\section{Research Methods}
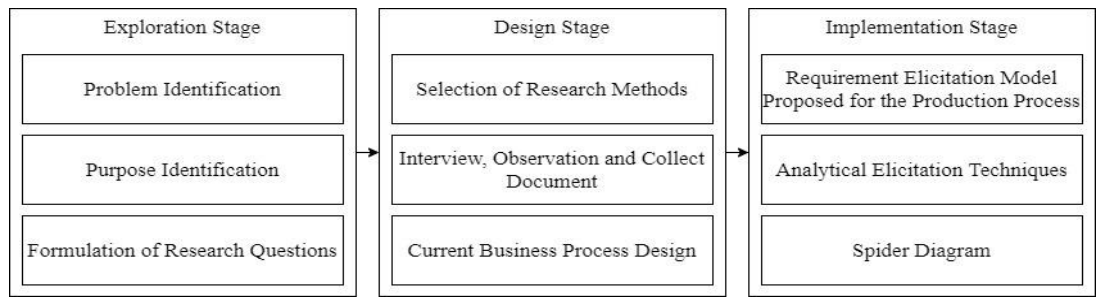

Fig. 1. Research Stages [23]. 
[24]:

Based on Figure 1, the following are the steps in the method from previous research

1. Exploration Stage. Identifying problems regarding the preparation of requirement elicitation. After that, identify objectives and formulate research questions.

2. Design Stage. We are selecting research by conducting interviews, observing and collecting documents. Then, the current business process design is carried out in a furniture manufacturing company.

3. Implementation Stage. Prepare a requirement elicitation model proposed for the production process. Then, analysis of elicitation techniques is carried out, and a requirement elicitation is generated in the form of a spider diagram.

\section{Result and Discussion}

\subsection{Exploration Stage}

The problems experienced by the furniture manufacturing industry started from mistakes when making an order letter entry by the marketing division. Order administration, such as selecting shipping methods, customer categories, order letter approval and e-catalogue approval, is often wrong. The process of sending data takes days. Incomplete data hinders the creation of sales invoices and travel documents. The process of withdrawing and migrating data takes a long time due to many data. This study aims to compile requirement elicitation:

- Identify requirement elicitation techniques needed in the production business area.

- Ordering the interests of the production business areas that need to be prioritized.

- Identifying problematic areas of the furniture production business.

The formulation of research questions is determined as follows:

Question 1: What are the production business areas that often experience problems?

Question 2: How important is requirement elicitation techniques to solve problems in the production business area?

Question 3: What are the business areas that must be prioritized in overcoming problems?

\subsection{Design Stage}

\subsubsection{Selection of Research Methods}

The results of the evaluation of the system planning technique that will be used for this study are shown in Table 1.

Table 1. Classification of Selected Requirement Elicitation Technique [25].

\begin{tabular}{|c|c|c|}
\hline Code & Description & \multirow{2}{*}{ Classification } \\
\cline { 1 - 2 } 1 & Brainstorming & \multirow{2}{*}{ Collaborative Technique } \\
\cline { 1 - 2 } 2 & Joint Application Development (JAD) & \multirow{2}{*}{ Contextual Technique } \\
\cline { 1 - 2 } 3 & Group Work & \\
\hline 4 & Interview & \multirow{2}{*}{ Observational Technique } \\
\hline 5 & Prototyping & \\
\hline 6 & Observation &
\end{tabular}


Table 1 explains that there are six elicitation techniques that will be used in this study to be combined with the Wellsandt evaluation criteria.

\subsubsection{Interview, Observation and Collect Document}

This research was conducted at Central Furniture Jepara, Hema Medhajaya and Lita Home Industry which process raw materials or semi-finished materials from wood, rattan and natural raw materials for all kinds of outdoor and indoor furniture, the main ingredients of teak and mahogany. In addition, research is also carried out in other furniture manufacturing industries focusing on chairs already used in various countries, including the Philippines, Thailand, Brunei, and various other Asian countries. The process of interview, observation and collecting documents is carried out to get an overview of current business processes and the profile of the company understudy.

\subsubsection{Current Business Process Design}

The current business process in the company starts from the marketing process to search for customers. Customers make a purchase order after viewing the model catalogue, and an order letter is made by marketing for approval by the sales manager and sales support. The results of the order letter approval are forwarded to the accounting department. The accounting department makes a Work Order (WO) which is passed on to the production department. The production department details the work order to check the availability of raw materials, supporting materials and leather fabrics in the warehouse. If the material is declared complete, the chair production process can be carried out. Chairs that have been produced will be collected in the form of a production module. The warehouse department makes a pass to be submitted to the accounting department. The accounting department creates a delivery pass, and the process of sending the goods to the customer's address is carried out. The accounting department makes financial reports.

\subsection{Implementation Stage}

\subsubsection{Requirement Elicitation Model Proposed for the Production Process}

Table 2. Requirement Elicitation Model of Production Process [26].

\begin{tabular}{|c|c|c|}
\hline Elements & Description & Business Area \\
\hline $\begin{array}{c}\text { Proximity To Use } \\
\text { (PTU) }\end{array}$ & $\begin{array}{c}\text { Applications can speed up } \\
\text { production times }\end{array}$ & $\begin{array}{c}\text { Production Scheduling, Production } \\
\text { Control }\end{array}$ \\
\hline Effort Per User (EPU) & Minimize production costs & Budget Preparation, Cash Management \\
\hline Required Skills (SKI) & $\begin{array}{c}\text { The applications ability to } \\
\text { analyze changes }\end{array}$ & $\begin{array}{c}\text { Project Management, Sales Market } \\
\text { Analysis, Personnel Planning }\end{array}$ \\
\hline Structure (STR) & $\begin{array}{c}\text { The information generated } \\
\text { can support multiple divisions }\end{array}$ & $\begin{array}{c}\text { Capacity Planning. Material } \\
\text { Requirements Planning }\end{array}$ \\
\hline Richness (RIC) & $\begin{array}{c}\text { Quality of information } \\
\text { generated }\end{array}$ & $\begin{array}{c}\text { Long Range Profit, Long Range Sales, } \\
\text { Short Term Sales }\end{array}$ \\
\hline Quantifiability (QUA) & $\begin{array}{c}\text { The quantity of information } \\
\text { from the proposed application }\end{array}$ & $\begin{array}{c}\text { Inventory/Stock Control, Research and } \\
\text { Development of New Products }\end{array}$ \\
\hline
\end{tabular}

The following describes the requirement elicitation model proposed to solve problems in the production process of a manufacturing company in Table 2 . Table 2 shows the use of 
Wellsandt's evaluation criteria to determine which business areas were frequently problematic before utilising the proposed application.

\subsubsection{Analytical Elicitation Techniques}

The following are the results of the evaluation of the elicitation technique and the Wellsandt criteria in Table 3.

Table 3. Evaluation of Elicitation Technique [20].

\begin{tabular}{|c|c|c|c|c|c|c|c|}
\hline \multirow{2}{*}{ Criteria } & \multirow{2}{*}{ Business Area } & \multicolumn{6}{|c|}{ Requirement Elicitation Technique } \\
\hline & & 1 & 2 & 3 & 4 & 5 & 6 \\
\hline \multirow{2}{*}{ PTU } & $\begin{array}{l}\text { Production } \\
\text { Scheduling }\end{array}$ & Low & Medium & High & Low & Medium & High \\
\hline & $\begin{array}{l}\text { Production } \\
\text { Control }\end{array}$ & Low & High & High & Low & Medium & Medium \\
\hline \multirow{2}{*}{ EPU } & $\begin{array}{c}\text { Budget } \\
\text { Preparation }\end{array}$ & High & Low & High & High & Low & Medium \\
\hline & $\begin{array}{c}\text { Cash } \\
\text { Management }\end{array}$ & High & Low & High & High & Low & Medium \\
\hline \multirow{3}{*}{ SKI } & $\begin{array}{c}\text { Project } \\
\text { Management }\end{array}$ & Medium & High & High & Medium & Medium & Medium \\
\hline & $\begin{array}{l}\text { Sales Market } \\
\text { Analysis }\end{array}$ & High & Low & Medium & High & Medium & High \\
\hline & $\begin{array}{l}\text { Personnel } \\
\text { Planning }\end{array}$ & Medium & Low & High & Low & Medium & Medium \\
\hline \multirow[b]{2}{*}{ STR } & $\begin{array}{l}\text { Capacity } \\
\text { Planning }\end{array}$ & High & High & High & Medium & Medium & Medium \\
\hline & $\begin{array}{c}\text { Material } \\
\text { Requirements } \\
\text { Planning }\end{array}$ & High & High & High & Low & Medium & Medium \\
\hline \multirow{3}{*}{ RIC } & $\begin{array}{l}\text { Long Range } \\
\text { Profit }\end{array}$ & High & Medium & Medium & Medium & Low & High \\
\hline & $\begin{array}{l}\text { Long Range } \\
\text { Sales }\end{array}$ & High & Medium & Medium & Medium & Low & High \\
\hline & $\begin{array}{l}\text { Short Term } \\
\text { Sales }\end{array}$ & High & Medium & Medium & Medium & Low & High \\
\hline \multirow[b]{2}{*}{ QUA } & $\begin{array}{c}\text { Inventory/Stock } \\
\text { Control }\end{array}$ & Low & Low & Medium & Low & Low & High \\
\hline & $\begin{array}{l}\text { Research and } \\
\text { Development of } \\
\text { New Products }\end{array}$ & High & Medium & Medium & High & Medium & High \\
\hline \multicolumn{2}{|r|}{ Total } & $\begin{array}{c}3 \mathrm{~L} ; 2 \\
\mathrm{M} ; 9 \mathrm{H}\end{array}$ & $\begin{array}{c}5 \mathrm{~L} ; 5 \\
\mathrm{M} ; 4 \mathrm{H}\end{array}$ & $\begin{array}{c}6 \mathrm{M} ; 8 \\
\mathrm{H}\end{array}$ & $\begin{array}{c}5 \mathrm{~L} ; 5 \\
\mathrm{M} ; 4 \mathrm{H}\end{array}$ & $\begin{array}{c}6 \mathrm{~L} ; 8 \\
\mathrm{M}\end{array}$ & $7 \mathrm{M} ; 7 \mathrm{H}$ \\
\hline
\end{tabular}

Notes : $\mathrm{L}=$ Low, $\mathrm{M}=$ Medium, $\mathrm{H}=$ High

The results of the classification of selected requirement elicitation techniques in Table 2 used in this study will be combined with the Wellsandt evaluation criteria and measured using a low, medium and large scale. Table 3 shows the results of the proposed requirements elicitation model: 
- Proximity To Use (PTU). The new system can arrange stock for the production of finished goods. Production scheduling can run smoothly because the production process does not follow the First In First Out (FIFO) rules. In production control, users can control incoming and outgoing raw materials.

- Effort Per User (EPU). The new system can determine the period in determining resources (raw materials, labour and production facilities) and contains information on the time and quantity of production.

- Required Skills (SKI). The new system can reduce the cost of furniture production, which hinders the mass production of products. In terms of sales market analysis, application users can find out which products are superior. Then, from the personnel planning area, each application user can know the job desk that must be done.

- Structure (STR). The proposed system can plan the capacity of the production process. Regarding material requirements planning, the proposed system can support the comparison of the estimated differences in material usage, buffer stock.

- Richness (RIC). Application users can estimate what furniture sales process can be done in the long and short term and estimate the benefits obtained from the sales.

- Quantifiability (QUA). On the inventory/stock control side, users can control a stock for production, warehouse and purchasing purposes. The research and development process of new products is by the intended market and furniture trends.

\subsubsection{Spider Diagram}
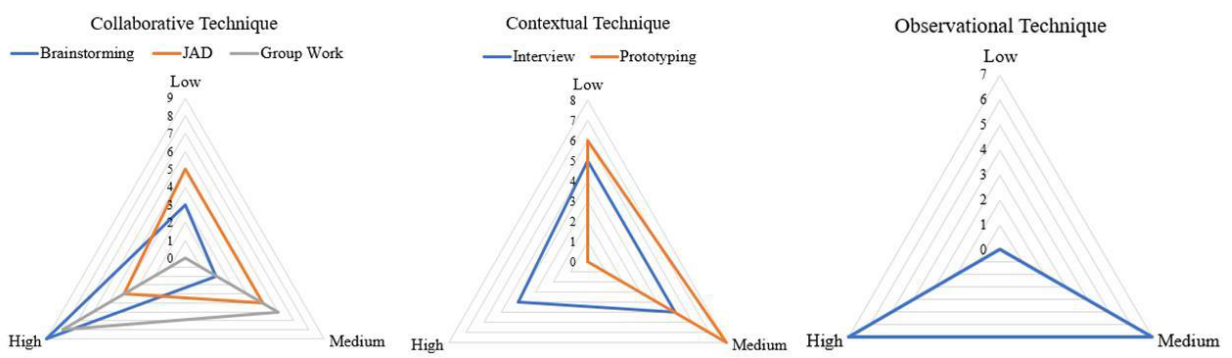

Fig. 2. Collaborative, Contextual, Observational Technique.

Based on Figure 2, shows the spider diagram collaborative, contextual and observational technique. This spider diagram states that there are still many business areas that need to be improved regarding the data collection process using three elicitation techniques. The difficulty level of each business area will be described in the form of a spider diagram that represents each technique.

The advantage of applying requirements elicitation in the manufacturing industry is that it can certainly help understand the problems that arise by translating inappropriate or incomplete needs and desires from users to obtain complete and precise specifications. The disadvantage of applying this requirement elicitation is that complete real-time data must support the specifications obtained. The business area you want to improve is the current manufacturing industry business processes. If the data is not real-time, errors or inaccuracies may appear in the assessment results of the manufacturing industry business area. 


\section{Conclusion}

The requirement elicitation process can determine user expectations and derive the most important requirements for program success. The proposed needs elicitation model in the production process is divided into five elements with their respective business areas. The Proximity to Use (PTU) element focuses on production scheduling and production control. The Effort Per User (EPU) element focuses on budgeting and cash management. The Required Skills (SKI) element focuses on project management, sales market analysis, and personnel planning. Elemental Structure (STR) focuses on capacity planning and material requirements planning. Elements of Richness (RIC) focuses on long-term profit forecasting, long-term sales forecasting, and short-term forecasting. The Quantifiability (QUA) element focuses on inventory/stock control and research and development of new products. The classification of the selected needs elicitation technique is combined with evaluation and measurement using a low, medium and large scale. Business areas on a "High" scale should be further improved because the whole process focuses on these techniques.

\section{References}

1. R. Morrar, H. Arman, and S. Mousa, "The Fourth Industrial Revolution (Industry 4.0): A Social Innovation Perspective," Technol. Innov. Manag. Rev., vol. 7, no. 11, pp. 159, 2017, doi: 10.22215/TIMREVIEW/1396, (2017)

2. D. Humphreys, "Mining Productivity And The Fourth Industrial Revolution," Miner. Econ., vol. 33, no. 1-2, pp. 115-125, 2020, doi: 10.1007/s13563-019-00172-9, (2020)

3. J. Wu, S. Guo, H. Huang, W. Liu, and Y. Xiang, "Information And Communications Technologies For Sustainable Development Goals: State-Of-The-Art, Needs And Perspectives," IEEE Commun. Surv. Tutorials, vol. 20, no. 3, pp. 2389-2406, 2018, doi: 10.1109/COMST.2018.2812301, (2018)

4. A. Szalavetz, "Industry 4.0 And Capability Development In Manufacturing Subsidiaries," Technol. Forecast. Soc. Change, vol. 145, no. June, pp. 384-395, 2019, doi: 10.1016/j.techfore.2018.06.027, (2019)

5. H. A. Nguyen, H. Nguyen, H. T. Nguyen, A. C. Phan, and Y. Matsui, "Empirical Study On The Role Of Collaboration In New Product Development In Manufacturing Companies," Int. J. Qual. Res., vol. 12, no. 2, pp. 363-384, 2018, doi: 10.18421/IJQR12.02-05, (2018)

6. S. Price and C. Reichert, "The Importance of Continuing Professional Development to Career Satisfaction and Patient Care: Meeting the Needs of Novice to Mid- to LateCareer Nurses throughout Their Career Span," Adm. Sci., vol. 7, no. 2, pp. 1-13, 2017, doi: 10.3390/admsci7020017, (2017)

7. M. Yaseen and U. Farooq, "Requirement Elicitation Model (REM) in the Context of Global Software Development," Int. J. Adv. Appl. Sci., vol. 7, no. 3, pp. 1-6, 2018, doi: 10.11591/ijaas.v7.i3.pp303-308, (2018)

8. Z. Ali, M. Yaseen, and S. Ahmed, "Effective Communication As Critical Success Factor During Requirement Elicitation In Global Software Development," Int. J. Comput. Sci. Eng., vol. 8, no. 3, pp. 108-115, (2019)

9. J. Hehn and F. Uebernickel, "Towards An Understanding Of The Role Of Design Thinking For Requirements Elicitation - Findings From A Multiple-Case Study," Am. Conf. Inf. Syst. 2018 Digit. Disruption, AMCIS 2018, no. September, pp. 1-11, (2018)

10. C. M. Dale, J. E. Angus, S. Sutherland, S. Dev, and L. Rose, "Exploration Of Difficulty Accessing The Mouths Of Intubated And Mechanically Ventilated Adults 
For Oral Care: A Video And Photographic Elicitation Study," J. Clin. Nurs., vol. 29, no. 11-12, pp. 1920-1932, 2020, doi: 10.1111/jocn.15014, (2020)

11. L. Taheri, M. Y. Shafazand, N. C. Pa, R. Abdullah, and S. Abdullah, "A Knowledge Audit Model For Requirement Elicitation: A Case Study To Assess Knowledge In Requirement Elicitation," Knowl. Process Manag., vol. 24, no. 4, pp. 257-268, 2017, doi: 10.1002/kpm.1553, (2017)

12. A. Zamansky, D. Van Der Linden, and S. Baskin, "Pushing Boundaries of RE: Requirement Elicitation for Non-human Users," Proc. - 2017 IEEE 25th Int. Requir. Eng. Conf., pp. 406-411, 2017, doi: 10.1109/RE.2017.30, (2017)

13. J. F. Andry, H. Tannady, and F. Nurprihatin, "Eliciting Requirements of Order Fulfilment in A Company," IOP Conf. Ser. Mater. Sci. Eng., vol. 771, pp. 1-6, 2020, doi: 10.1088/1757-899X/771/1/012023, (2020)

14. R. S. D. Astuti, A. D. Astuti, and Hadiyanto, "Preliminary Design of Industrial Symbiosis of Smes Using Material Flow Cost Accounting (MFCA) Method," E3S Web Conf., vol. 31, pp. 1-7, 2018, doi: 10.1051/e3sconf/20183104008, (2018)

15. M. Soori and M. Asmael, "Classification of Research and Applications of the Computer Aided Process Planning in Manufacturing Systems," Indep. J. Manag. Prod., pp. 1-33, 2020, doi: 10.14807/ijmp.v12i5.1397, (2020)

16. M. A. Bagherian et al., "Classification and Analysis of Optimization Techniques for Integrated Energy Systems Utilizing Renewable Energy Sources: A Review for CHP and CCHP Systems," Processes, vol. 9, no. 2, pp. 1-36, 2021, doi: 10.3390/pr9020339, (2021)

17. C. Rujikiatkamjorn and B. Indraratna, "An Evaluation Of Vacuum Consolidation Performance Using Observational Techniques," ICSMGE 2017 - 19th Int. Conf. Soil Mech. Geotech. Eng., vol. September, pp. 2643-2646, (2017)

18. K. B. Ameyaw, K. N. Ofori, B. Adjepong, and H. D. Assem, "Using Observational Techniques as Assessment Instruments to Improve Learners' Performance at Nkawkaw, Ghana," IOSR J. Res. Method Educ., vol. 8, no. 6, pp. 87-96, 2018, doi: 10.9790/7388-0806048796 (2018)

19. H. Schulz, V. Ferme, D. Okanovic, A. Van Hoorn, and C. Pautasso, "Behavior-Driven Load Testing Using Contextual Knowledge - Approach And Experiences," ICPE 2019 - Proc. 2019 ACM/SPEC Int. Conf. Perform. Eng., pp. 265-272, 2019, doi: 10.1145/3297663.3309674, (2019)

20. O. J. Okesola, K. Okokpujie, R. G. Worlu, A. Ogunbanwo, and O. Iheanetu, "Qualitative Comparisons Of Elicitation Techniques In Requirement Engineering," ARPN J. Eng. Appl. Sci., vol. 14, no. 2, pp. 565-570, (2019)

21. U. Rafiq, S. S. Bajwa, X. Wang, and I. Lunesu, "Requirements Elicitation Techniques Applied In Software Startups," Proc. - 43rd Euromicro Conf. Softw. Eng. Adv. Appl. SEAA, pp. 141-144, 2017, doi: 10.1109/SEAA.2017.73, (2017)

22. T. Y. Lim, F. F. Chua, and B. B. Tajuddin, "Elicitation Techniques For Internet Of Things Applications Requirements: A Systematic Review," ACM Int. Conf. Proceeding Ser., pp. 182-188, 2018, doi: 10.1145/3301326.3301360, (2018)

23. S. Wellsandt, K. A. Hribernik, and K. D. Thoben, "Qualitative Comparison Of Requirements Elicitation Techniques That Are Used To Collect Feedback Information About Product Use," Procedia CIRP, vol. 21, pp. 212-217, 2015, doi: 10.1016/j.procir.2014.03.121, (2015)

24. M. Yousuf, "Comparison of Requirements Elicitation Techniques," Int. J. Adv. Comput. Inf. Technol., vol. 1, no. 4, pp. 378-387, 2016, doi: 10.6088/ijacit.12.14005, 
(2016)

25. M. K. Sabariah, P. I. Santosa, and R. Ferdiana, "Requirement Elicitation Framework For Child Learning Application-A Research Plan," ACM Int. Conf. Proceeding Ser., pp. 129-133, 2019, doi: 10.1145/3305160.3305195, (2019)

26. Y. Duan and R. Kinman, "Small Manufacturing Businesses: Meeting Decision Support Needs," J. Small Bus. Enterp. Dev., vol. 7, no. 3, pp. 272-284, 2016, doi: 10.1108/EUM0000000006845, (2016) 